\title{
SYNTHESIS POLYMER MATRIX COMPOSITE EPOXY FeNdB-Cu FOR RADAR ABSORBER COATING APPLICATION
}

\author{
S. M. Latifah ${ }^{1}$, D. H. Prajitno ${ }^{1,2}$ and M. F. Syukron ${ }^{1}$ \\ ${ }^{1}$ Metallurgical Engineering, FTM-Universitas Jenderal Achmad Yani, Bandung, Indonesia \\ ${ }^{2}$ PSTNT BATAN, Jl. Taman Sari N.71, Bandung, 40123, Indonesia \\ E-mail: sri.mulyati@lecture.unjani.ac.id
}

Received: 10 January 2021

Revised: 15 April 2021

Accepted: 22 April 2021

\begin{abstract}
SYNTHESIS POLYMER MATRIX COMPOSITE EPOXY FeNdB-CU FOR RADAR ABSORBER COATING APPLICATION. Radar (Radio Detection and Ranging) is a technology using the principle of electromagnetic for detecting, measuring, and mapping target coordinates. So stealth technology was created to tackle these threats, one of which is the radar absorber coating method (RAC). This research aims to identify the effect addition of $\mathrm{Cu}$ to $\mathrm{Fe}-\mathrm{Nd}-\mathrm{B}$ radar absorber material as polymer matrix composite (PMC). The processes were done by powder metallurgy method, started by milling and mechanical alloying process using planetary ball mill for 60 minutes $1000 \mathrm{rpm}, 25 \mathrm{~kg} / \mathrm{mm}^{2}$ of compaction load, and sintering at the temperature $1000{ }^{\circ} \mathrm{C}$ for 3 hours. The coating process was carried out conventional method as much as 1 layer, the variation of resin and magnetic powder are (95:5), (90:10), and (85:5) with the addition of Cu 1\%wt. Based on the characterization the lowest RL was obtained at the composition $(85: 15)$ with the value $32.08 \mathrm{~dB}$ at the frequency of $10.36 \mathrm{GHz}$, magnetic characterization after doping addition coercivity $0.096 \mathrm{kOe}$ and Saturation $5.22 \mathrm{kG}$. PMC hardness was raising following to addition of magnetic powder with the 29.2 HD Shore D, and adhesivity value was decreased following to addition of magnetic powder to $0.5 \mathrm{MPa}$.
\end{abstract}

Keywords: Polymer Matrix Composite, Radar Absorber Coating, FeNdB, Coercivity, Reflection Loss

\begin{abstract}
ABSTRAK
SINTESIS MATRIKS POLIMER KOMPOSIT EFOKSI FeNdB-CU UNTUK APLIKASI LAPISAN PENYERAP RADAR. Radar (Radio Detection and Ranging) adalah teknologi yang menggunakan prinsip elektromagnetik untuk mendeteksi, mengukur, dan memetakan koordinat target. Maka dibuatlah stealth technology untuk menanggulangi ancaman tersebut, salah satunya adalah metode radar absorber coating (RAC). Tujuan penelitian ini adalah untuk melihat pengaruh penambahan doping $\mathrm{Cu}$ terhadap material penyerap gelombang FeNdB sebagai polymer matrix composite (PMC). Proses dilakukan dengan metalurgi serbuk, diawali milling dan mechanical alloying menggunakan planetary ball mill selama 60 menit $1000 \mathrm{rpm}$, selanjutnya dikompaksi pada pembebanan $25 \mathrm{~kg} / \mathrm{mm}^{2}$, dan sintering pada temperatur $1000{ }^{\circ} \mathrm{C}$ selama $3 \mathrm{jam}$. Proses coating dilakukan dengan metode konvensional sebanyak 1 layer, variasi resin dengan serbuk magnetik yaitu (95:5), (90:10), dan (85:5) dengan penambahan doping Cu sebanyak 1\%wt. Hasil pengujian didapat nilai RL terendah pada komposisi (85:15) yaitu $-32,08 \mathrm{~dB}$ pada frekuensi $10,36 \mathrm{GHz}$, karakteristik magnetik setelah penambahan doping dengan nilai koersivitas 0,096 kOe dan saturasi 5,22 kG. kekerasan PMC meningkat seiring penambahan serbuk magnetik 29,2 HD Shore D, dan adhesivitas menurun seiring penambahan serbuk magnetik menjadi $0,5 \mathrm{MPa}$.
\end{abstract}

Kata kunci: Polymer Matrix Composite, Radar Absorber Coating, FeNdB, Koersivitas, Reflection Loss 


\section{INTRODUCTION}

Radar (Radio Detection and Ranging) is a technology using the principle of electromagnetic for detecting, measuring, and mapping target coordinates. This is supported by the opinion of Pradoto [1] that threat for the existence of a ship or airplane started since the discovery of radar in England in 1930. The development of radar needs to be balanced by other technology intended to avoid being watched by radar and as known as stealth technology. This technology basically used for disguise distance monitoring from enemy's radar at airplane, ship, missile, and military vehicle making it difficult to being watched by a system of radar, infrared, heat, and another method. The effectivity of the radar system in detecting the targets is depending on how much electromagnetic energy which is reflected by the object and received again by radar. This is defined as the radar cross section. One of the methods to reduce the RCS is Radar Absorber Coating.

Then one way to avoid radar detection is using material that has the characteristics of absorbing radar material. Among them are magnets. Three important characteristics that describe magnets performance is magnetic induction remanence $(\mathrm{Br})$, Coercivity $(\mathrm{Hc})$, and maximum energy product (BHmax). Permanent magnets Neodymium-Iron-Boron always attracts a lot of attention since founded in 1980 because of the performance [2] With the consideration of $\mathrm{NdFeB}$ advantage, the research of this material needed to maximize.

To improve the magnetic properties by increasing the corsivity value of $\mathrm{FeNdB}$ besides doping with rare earth $\mathrm{Tb}_{75-\mathrm{x}} \mathrm{Ce}_{\mathrm{x}} \mathrm{Cu}_{25}$ alloy powder [3], rare earth Pr-Zn [4] and the passivation process of $\mathrm{NdFeB}$ with $\mathrm{Zn}$, the passivation layer on the surface of the $\mathrm{Zn}$ coating also contributes to the increase corrosion resistance [5]. In addition to the above doping, the increase in the coefficient of coercivity can also be done with anisotropic multi-component nanocomposites $(\mathrm{SmCo}+\mathrm{FeCo}) / \mathrm{NdFeB}[6]$.

On its development the research about radar absorber material has done a lot with powder metallurgy with the final product of radar absorber material is compaction result, then further research is needed to get protection method from radar more effectively and efficiently for technology and military equipment development. Which demands effectivity and high mobility. Among them are coating method.

From the thing that has been stated above, this research takes the theme of" Synthesis Polymer Matrix
Composite Epoxy-FeNdB-Cu for Radar Absorber Coating Application". The choice of copper $(\mathrm{Cu})$ as $\mathrm{FeNdB}$ dopping was due to the fact that $\mathrm{Cu}$ has a large conductivity and tends to increase the density value, thereby reducing porosity and increasing magnetic properties [7].

\section{EXPERIMENTAL METHOD}

\section{Materials and Instruments}

The synthesis of polymer matrix composite as a Radar absorber Coating using epoxy resin (yukalac) as a matrix and FeNdB powder that has been doped with $\mathrm{Cu}$ as a magnetic material. The variations in the composition of epoxy resin and magnetic powder are 95: 5, $90: 10$, and $85: 15$. while $\mathrm{Cu}$ in the form of a pro analysis powder was nanopaarticle size. The FeNdB matrix, which was originally a chip, became a particle powder material using a Planetary ball mill PQ-N2. Than milling process and $\mathrm{Cu}$ doping were carried out using a Planetary Ball Mill PQ-N2 at a speed of $1000 \mathrm{rpm}$ for 1 hour, 2 vials were used with the composition per vial filled with 4.95 grams $\mathrm{FeNdB}$. While $\mathrm{Cu}$ in the form of a pro analysis powder was micro-paarticle size with weight 0.05 grams $\mathrm{Cu}$.

\section{Method and Procedure}

The process method used is powder metllurgy with the stages of mechanical alloying or milling, compacting and sintering. The method mechanical alloying used is dry milling with planetary ball mill PQ-N2 and SS 304 ball mill materials for 1 hours with a rotation speed of $1000 \mathrm{rpm}$. After the mixing process, two different processes were carried out to obtain the target test data. There is a compacting process to obtain a sample in the form of a pellet with an emphasis of $25 \mathrm{kG}$ $/ \mathrm{mm} 2$ with a final dimension of $\mathrm{D}=11 \mathrm{~mm}$, thick $=5 \mathrm{~mm}$, then the sintering process is carried out for 3 hours with a temperature of $1000{ }^{\circ} \mathrm{C}$ and a pressure of 1 Atm under atmospheric conditions. $\mathrm{Cu}$-doped $\mathrm{FeNdB}$ was sintered at $\mathrm{T} 1000{ }^{\circ} \mathrm{C}$ which is expected to have good magnetic properties and magnetic thermal stability [3]. For XRD testing is Shimadzu machine, with the target material using a $\mathrm{Cu}$ anode, the test is carried out with a star position at $2 \theta$ at $10^{\circ}$ while the final test position is at $2 \theta$ at $100^{\circ}$. Magnetic testing uses Permagraph testing with machine used Magnet Physik Dr. Steingroever GmbH D 5000 Koln 50 W-Germany, Koln W-Germany, Type/Serial No EP2/ 
100053, Factory Brand $=$ MPS/Germany, RBUBM location. For SEM-EDS testing using Hitachi Brand machine Model SU 3500. Replection loss testing using a VNA testing type AV3672A-S (ADVANTEST R3770).

In addition to the compacting process, there is the formation of other samples for the coating process. The powder that has been mixed is homogenized into the resin with a stirring time of 15 minutes. After the homogenization process is complete, PMC is applied to the surface of the substrate which has been pre-prepared by sanding it using sandpaper 240 and 400 mesh. The coating application process is carried out conventionally using brush number 5 .

The substrate that has been given a coating treatment is then tested using the AV3672A-S Vector Network Analyzer with a frequency range of $8-12 \mathrm{GHz}$, hardness with Durometer Shore D (ASTM D 2240 Standard), Adhesiveness testing with Elcometer model 106 Adhesion Tester (ASTM D 4541 Standard), and thickness measurement using a 200x magnification digital microscope. Adhesiveness testing with Elcometer model 106 Adhesion Tester (ASTM D 4541 Standard), and thickness measurement using a 200x magnification digital microscope for Metallography, VNA, Hardness and adhesivity testing.

\section{RESULTS AND DISCUSSION}

The synthesis process of wave-absorbing PMC is carried out with 3 main ingredients: Epoxy resin, FeNdB, and $\mathrm{Cu}$ doping. The choice of Epoxy Resin aims to minimize the presence of other additives contained in the matrix (Resin), FeNdB is used because its absorption rate is up to 13.1 MGOe which is 10 times greater than $\mathrm{BaFeO}[8]$ As well as the reasons for the addition of $\mathrm{Cu}$ doping based on the permeability, type resistance, and high conductivity value of copper. so that it is suitable for doping in RAM, besides that, the addition of copper doping tends to increase the density value, decrease porosity, and increase its magnetic properties [8].

\section{Permagraph}

In the permagraph test data, there was an increase in the coercivity value from $0.072 \mathrm{kOe}$ to $0.096 \mathrm{kOe}$, this is due to the failure of the $\mathrm{Cu}$ element as a doping to substitute the $\mathrm{Fe}$ ion. However, there was an increase in the magnetic saturation value so that the magnetic level of the sample increased from $4.90 \mathrm{kG}$ to $5.22 \mathrm{kG}$ as in Figure 1 and Table 1. The requirement for the radar

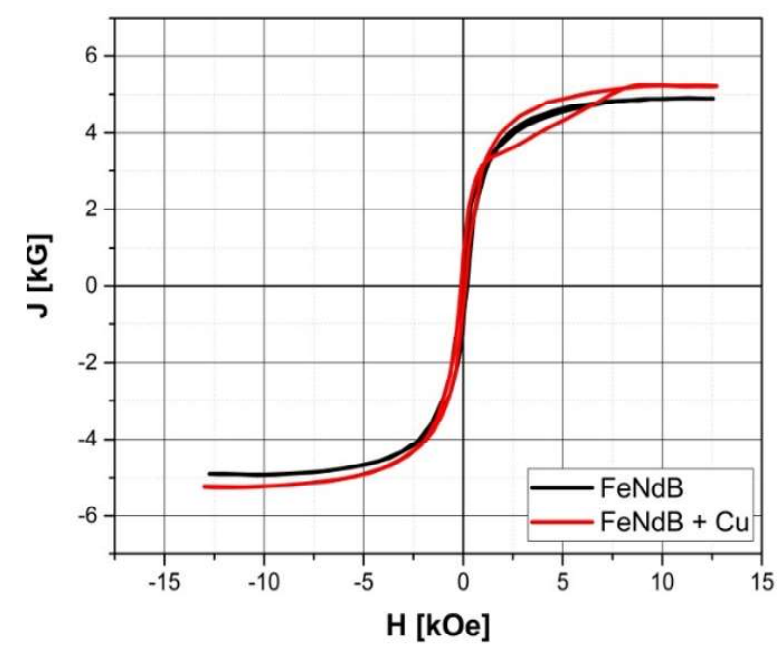

Figure 1. Loop Histerisis Graphic for Magnetic Materials.

absorber itself is that it must have a narrow hysteresis loop with the smallest possible coercivity value $<0.2 \mathrm{kOe}$ and the highest possible saturation value $[8,9]$.

Table 1. Permagraph Data

\begin{tabular}{llll}
\hline Sampel & $\begin{array}{l}\text { Rema- } \\
\text { nansi, Mr } \\
\text { (kG) }\end{array}$ & $\begin{array}{l}\text { Coorsi- } \\
\text { vity, HcJ } \\
\text { (kOe) }\end{array}$ & $\begin{array}{l}\text { Satu- } \\
\text { rasi, } \\
\text { Ms } \\
(\mathbf{k G )}\end{array}$ \\
\hline FeNdB & 0.161 & 0.072 & 4.90 \\
FeNdB + & 0.939 & 0.096 & 5.22 \\
Cu & & & \\
\hline
\end{tabular}

The increase in the coercivity value is due to the failure of $\mathrm{Cu}$ ions to substitute $\mathrm{Fe}$ ions due to the presence of cracks in the material as mentioned by Callister [10] that the coercivity value is sensitive to structural changes. Defects (crack) in the material can increase the coercivity value. And the increase in coercivity was due to the lack of doping proportion added by $1 \% \mathrm{Cu}$ so that there was no substitution of $\mathrm{Fe}$ ions by $\mathrm{Cu}$. $\mathrm{Cu}$-doped $\mathrm{FeNdB}$ not only increases the cooesivity of the magnetic properties of, it also has a positive effect on corrosion resistance which can be increased by the diffusion of $\mathrm{Cu}$ at the grain boundaries $[11,12]$. Beside The element $\mathrm{Cu}$, the addition of elements such as Tb-Ce- to FeNDB will increase the coorcivity and thermal stability of FeNdB magnets [3].

\section{XRD}

According to the XRD test results that appear are compounds $\mathrm{Nd}_{2} \mathrm{Fe}_{14} \mathrm{~B}, \mathrm{Cu}_{5} \mathrm{Nd}$, and $\mathrm{NdB}_{6}$, where the $\mathrm{Cu}_{5} \mathrm{Nd}$ peak is very small, this is supported by the opinion of Windu which states that the greater the ion substitute make the coercivity value smaller [8]. From the XRD 
results obtained $\mathrm{Nd}_{2} \mathrm{Fe}_{14} \mathrm{~B}$ type with dopping $\mathrm{Cu}$ usually RE-rich phase atoms will substitute for $\mathrm{Nd}$, while $\mathrm{Cu}$ will be distributed mainly at grain boundaries [12]. In addition, there was an increase in the magnetic saturation properties from $4.90 \mathrm{kG}$ to $5.22 \mathrm{kG}$, which means that there was a significant increase in the magnetization after the addition of $\mathrm{Cu}$ doping.

$\mathrm{XRD}$ testing is carried out to identify the compounds formed in the test material. The sample used in the XRD test is a pellet that has been through a powder
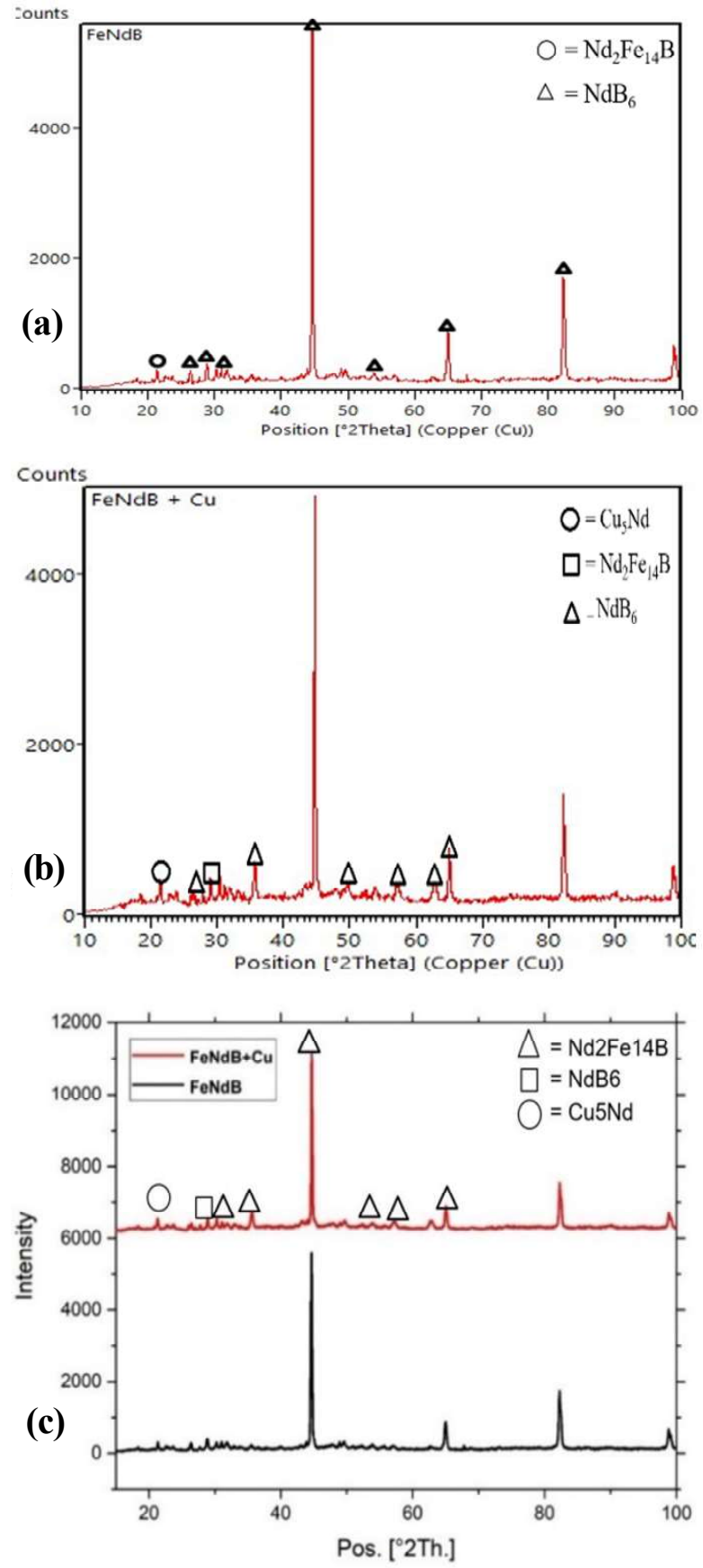

Figure 2. XRD FeNdB Diffraction Pattern (a) Pure $\mathrm{FeNdB}$, (b) $\mathrm{FeNdB}+\mathrm{Cu}$ and (c) Comparison of $\mathrm{FeNdB}$ and $\mathrm{FeNdB}+\mathrm{Cu}$ metallurgy process and sinterig for 3 hours at a temperature of $1000^{\circ} \mathrm{C}$.

The predominantly formed compound was $\mathrm{Nd}_{2} \mathrm{Fe}_{14} \mathrm{~B}$ accompanied by the presence of the $\mathrm{NdB}_{6}$ compound, after the addition of the doping element, $\mathrm{Cu}_{5} \mathrm{Nd}$ compounds appeared in the sample. The addition of a number of $\mathrm{Cu}$ can substitute the element of $\mathrm{Fe}$ so that the compound formed is $\mathrm{Nd}_{2} \mathrm{Cu}_{14} \mathrm{~B}$ supported by the size of the atomic radii of $\mathrm{Fe}$ and $\mathrm{Cu}$ which are almost the same. However, the substitution process for Fe by $\mathrm{Cu}$ has not yet occurred, one of the reasons is the lack of addition of $\mathrm{Cu}$ doping so that $\mathrm{Cu}$ does not fully react to form $\mathrm{Nd}_{2} \mathrm{Cu}_{14} \mathrm{~B}$, but instead forms $\mathrm{NdCu}_{6}$. Changes in compounds formed after doping additions can be seen in Figure 2, in Pos. [2Th.] 35.65 new peaks appeared as well as the addition of $\mathrm{Cu}_{5} \mathrm{Nd}$ and $\mathrm{NdB}_{6}$ compounds.

\section{SEM-EDS}

SEM testing is carried out to review the distribution and size of powder that has been carried out by the milling process. Based on the tests that have been carried out, there is still a non-uniform powder size. The

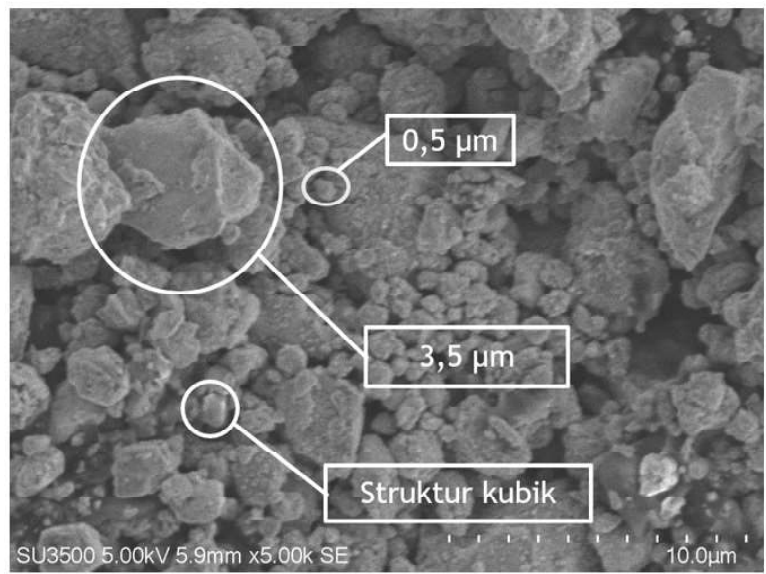

Figure 3. Microstructure 5.000x Magnification

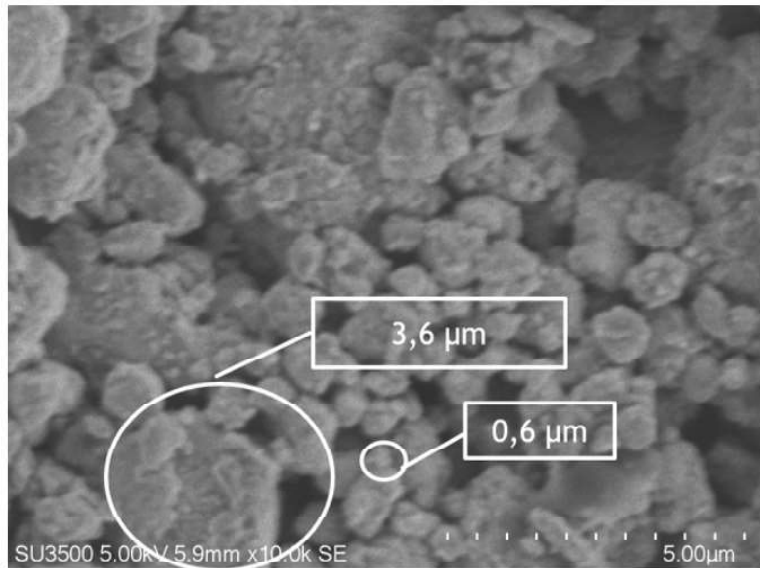

Figure 4. Microstructure 10.000x Magnification 
largest powder size was $3.5 \mu \mathrm{m}$ due to agglomeration and the smallest was $0.5 \mu \mathrm{m}$. the largest grain was $3.6 \mu \mathrm{m}$ in size and the smallest was $0.5 \mu \mathrm{m}$ in size. The resulting powder is at a micron scale with a cubic crystal structure as shown in Figure 3 and 4.

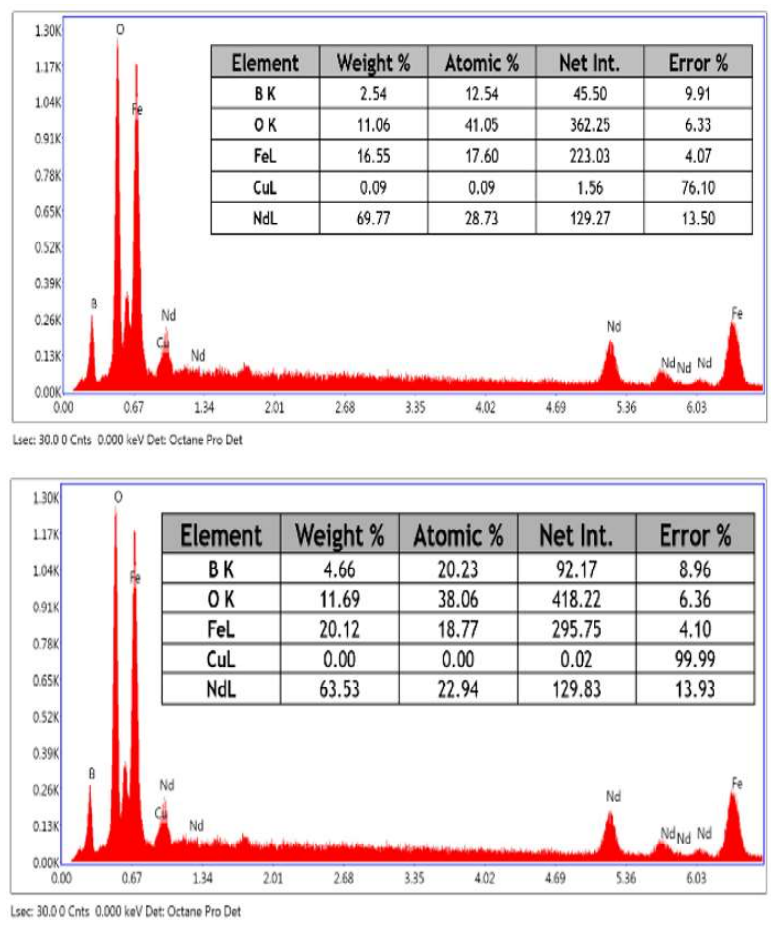

Figure 5. EDS Test Result

The EDS test in Figure 5 shows that the dominant element in the test sample is the $\mathrm{Nd}$ element with a percentage of $69.77 \%$, followed by $16.55 \% \mathrm{Fe}$, and $2.54 \%$ B. The addition of $\mathrm{Cu}$ doping in the sample was $1 \%$, only $0.09 \%$ appeared in the EDS test with a high error rate of $76.10 \%$. The presence of elemental $\mathrm{O}$ is caused by storing the sample for a long time so that the material is oxidized.

\section{Vector Network Analyzer}

Vector network analyzer (VNA) testing is carried out in the $8 \mathrm{GHz}-12 \mathrm{GHz}$ frequency range, this range is used because it is a frequency commonly used for detection radars. In Figure 6 and Table 2 the reflection loss value increases as the percentage of magnetic powder in PMC increases with the values being $-6.34 \mathrm{~dB}$ (Epoxy Resin 95: Magnetic Powder 5), -18.84 dB (Epoxy Resin 90: Magnetic Powder 10), -32.08 dB (Epoxy Resin 85: Magnetic Powder 15).

$$
\begin{aligned}
& \Gamma=10^{\frac{R L}{20}} \\
& \% \text { Penyerapan }=100(1-\Gamma)
\end{aligned}
$$

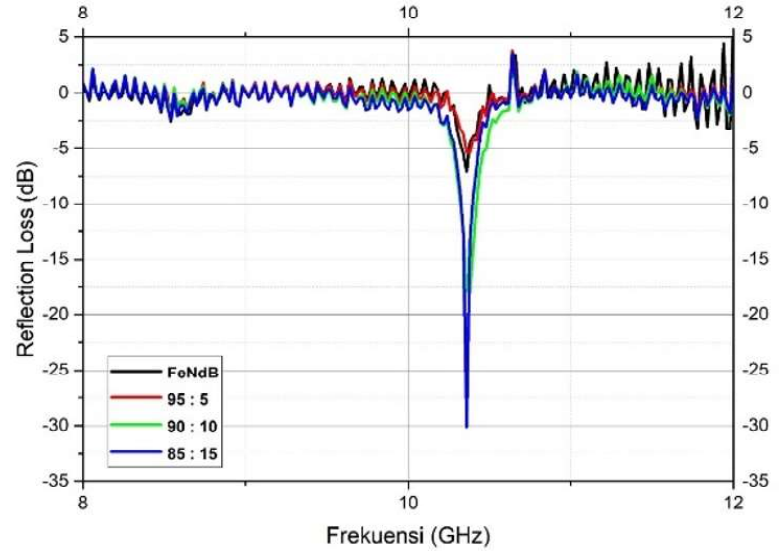

Figure 6. Vector Network Analyzer Graph

The increase in the reflection loss value is a positive thing because the smaller the reflection loss value obtained, the more difficult it is for PMC to be detected by radar. Optimizing the reflection loss value also increases the absorption percentage with the most optimal up to $99 \%$ in the addition of $15 \%$ powder.

The addition of $\mathrm{Cu}$ doping was proven to increase the reflection loss level, in PMC with FeNdB powder content without doping the value was $-7.95 \mathrm{~dB}$, while after the addition of doping the value was -18.84 $\mathrm{dB}$ which was more than twice that. This is due to the addition of $\mathrm{Cu}$ doping to $\mathrm{FeNdB}$ can increase magnetic properties, one of which is the high is saturation magnetic property and low coorcivity value, so that $\mathrm{FeNdB}$ which is originally a hard magnet becomes a soft magnet, therefore it will increase the replection loss value.

After the addition of $\mathrm{Cu}$ doping, there was a change in the magnetic value, there was a significant increase in the magnetic saturation to $5.22 \mathrm{kG}$. Increasing the saturation value in magnetic material results in an increase in the degree of magnetization, saturation magnetization is a state where the magnetic spins in the material are in the same direction as the external magnetic field [2] the more direction the magnetic domain in the

\begin{tabular}{|c|c|c|c|c|c|}
\hline No & $\begin{array}{l}\text { PMC } \\
\text { (Epoxy: } \\
\text { FeNdB+Cu) }\end{array}$ & $\begin{array}{l}\text { F } \\
(\mathrm{GHz}))\end{array}$ & $\begin{array}{l}\text { Reflect } \\
\text { ion } \\
\text { Loss } \\
\text { (dB) }\end{array}$ & $\begin{array}{l}\text { Absor } \\
\text { bing } \\
\text { Coefisi } \\
\text { ent } \\
(\Gamma)\end{array}$ & $\begin{array}{l}\text { Absorbing } \\
\text { percentace } \\
(\%)\end{array}$ \\
\hline 1 & $\begin{array}{l}\text { 95:5 } \\
\text { (doped Cu) }\end{array}$ & 10.38 & -6.34 & 0.4814 & 51.86 \\
\hline 2 & $\begin{array}{l}90: 10 \\
\text { (without } \\
\text { Cu) }\end{array}$ & 10.36 & -7.95 & 0.1142 & 88.58 \\
\hline 3 & $\begin{array}{l}90: 10 \\
\text { (doped Cu) }\end{array}$ & 10.38 & -18.84 & 0.4216 & 57.84 \\
\hline 4 & $\begin{array}{l}\text { 85:15 } \\
\text { (doped Cu) }\end{array}$ & 10.36 & -32.08 & 0.0248 & 99.0248 \\
\hline
\end{tabular}

Table 2. Reflection Loss data Result 
material is, the more waves can be absorbed, thereby increasing the reflection loss value in PMC more than twice from $-7.95 \mathrm{~dB}$ to $-18.84 \mathrm{~dB}$ can be seen in Figure 7 .

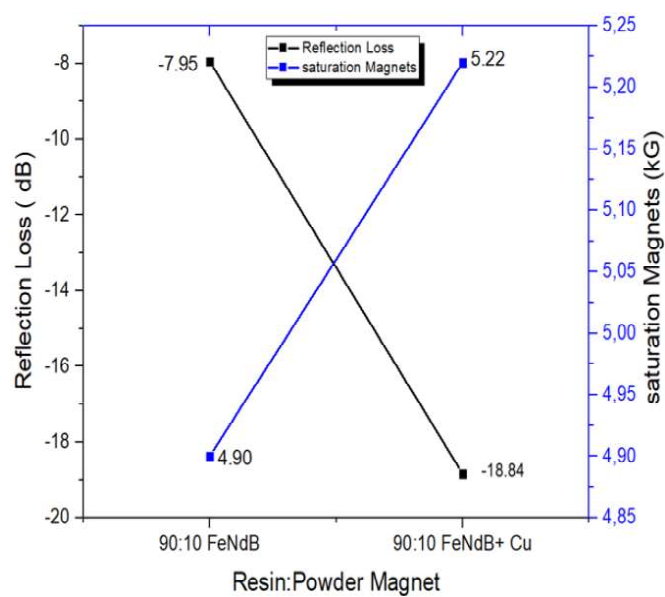

Figure 7. Effect of Magnetic Saturation Value on Reflection Loss

\section{Hardness}

The results of hardness testing using Durometer of type D is a tool used to measure the hardness of polymer. The shore used is type $\mathrm{D}$ which is designed for applications of Hard rubber, thermoplastic, elastomers, harder plastics, and rigid thermoplastics. The Hardness testing data can be seen At PMC with a higher percentage of magnetic powder content, a higher level of hardness was obtained, with values of $20.9 \mathrm{HD}$ (100\% resin), $24 \mathrm{HD}$ (95\% resin: 5\% magnetic powder), respectively; 26.3 (90\% resin: 10\% Magnetic powder); 29.2 (85\% resin: 15\% Magnetic powder) as shown in Figure 8.

The addition of a metal alloy to the epoxy resin can increase the strength and hardness by adding a percentage of the volume of fine particles dispersed to the polymer. The reinforcement that occurs involves the interaction between particles and dislocations within the

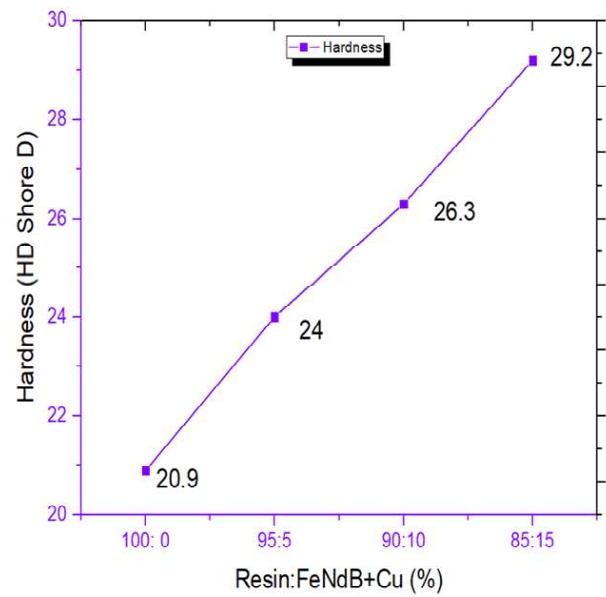

Figure 8. Hardness Average Graphic matrix as occurs in the strengthening of precipitates [8]. In this study, the addition of FeNdB magnetic powder doped with copper, besides functioning as an additive to absorb waves, also functions as a reinfercoment in PMC. The more the magnetic powder dispersed, the increased the hardness and strength produced by the polymer matrix composite.

\section{Adhesivity}

Adhesivity testing is carried out to measure the level of adhesion of the coating to the substrate, the standard used is ASTM D4541 with test results can be seen in Table 3. And Figure 9.

In the adhesive test, there was a decrease in the level of adhesiveness for each addition of magnetic powder. In Figure 9 The data obtained sequentially are 2 Mpa (100\% epoxy resin), $1.2 \mathrm{Mpa}$ (95\% epoxy resin: $5 \%$ magnetic powder), $0.9 \mathrm{Mpa}$ (90\% epoxy resin: $10 \%$ magnetic powder), and $0.5 \mathrm{Mpa}$ ( $85 \%$ epoxy resin: $15 \%$ magnetic powder).

There are a number of bonding types that occur in the coating polymer. The type of bonding in this research that occurs is mechanical adhesion which is defined as the presence of a number of adhesive streams attached to a substrate which is assisted by surface roughness, with epoxy resin as the adhesive substance

Table 3. Adhesivity characterization data

\begin{tabular}{ccc}
\hline No. & $\begin{array}{c}\text { Resin : FeNdB }+ \\
\text { Cu (\%) }\end{array}$ & $\begin{array}{c}\text { Adhesivitas } \\
\text { Force (Mpa) }\end{array}$ \\
\hline 1 & 100 (Resin) & 2 \\
2 & $95: 5$ & 1,2 \\
3 & $90: 10$ & 0,9 \\
4 & $85: 15$ & 0,5 \\
\hline
\end{tabular}

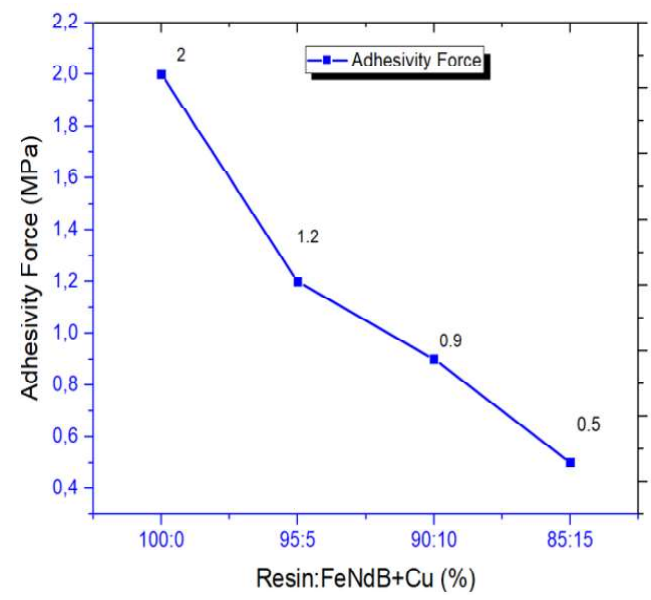

Figure 9. Adhesivity Graphic 
alumunium substrate which has been subjected to mechanical surface preparation which also aims to provide a number of hardness on the surface to cause an interlock between the epoxy resin and the substrate.

The decreasing trend of the adhesive value on the increase in the percentage of powder was due to the reduced resin content in the PMC which had the ability to adhere to the substrate, the more magnetic powder distributed on the PMC reduced the percentage of resin surface adhering to the substrate.

The adhesiveness value is inversely proportional to the hardness value possessed by the wave-absorbing coating, this is due to the increasing percentage of magnetic powder, the more fine powder is dispersed in the PMC, thus increasing the hardness, on the other hand the more magnetic powders in the coating result in reduced adhesiveness due to reduced resin percentage as can be seen in the Figure 10. From Figure 10 the comparison of the highest value of hardness is 29.2 Hardness Shore D and the value of the adhesivity force is $2 \mathrm{MPa}$. This value is in accordance with PMC + FeNdBMn material with hardness and adhesion values 29.1 Hardness Shore D and $2 \mathrm{MPa}$ [13].

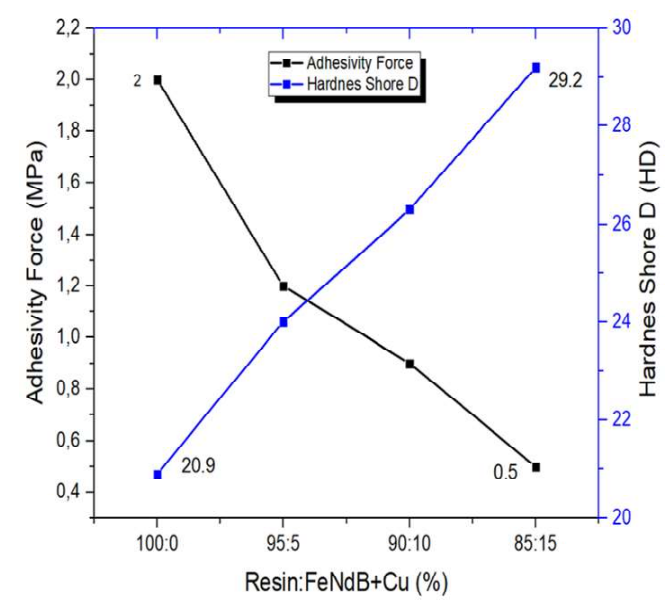

Figure 10. Comparison Hardness and Adhesivity [13]

\section{CONCLUSIONS}

Based on SEM-EDS, the largest grain size was $3.6 \mathrm{~mm}$ and the smallest was $0.5 \mathrm{~mm}$ in size. The crystal structure formed was the cubic structure. The dominant element found in the sample is $\mathrm{Nd}(69.77 \%)$. The dominant compound formed was $\mathrm{Nd}_{2} \mathrm{Fe}_{14} \mathrm{~B}$ with the appearance of $\mathrm{Cu}_{5} \mathrm{Nd}$ after adding doping.

The PMC hardness value increased with the addition of magnetic powder with the values of $20.9 \mathrm{HD}$ (100\% resin), 24 HD (95\% resin: 5\% magnetic powder), respectively; 26.3 (90\% resin: 10\% Magnetic powder); 29.2 (85\% resin: 15\% magnetic powder) and PMC adhesiveness decreased with the addition of magnetic powder with a value of $2 \mathrm{Mpa}$ (100\% epoxy resin), 1.2 Mpa (95\% epoxy resin: 5\% magnetic powder), 0, 9 Mpa (90\% epoxy resin: $10 \%$ magnetic powder), and $0.5 \mathrm{Mpa}$ ( $85 \%$ epoxy resin: $15 \%$ magnetic powder).

For magnetic characterization, there was an increase in the coercivity value after the addition of doping from $0.072 \mathrm{kOe}$ to $0.096 \mathrm{kOe}$, but still, in the soft magnet criteria, there was also an increase in the saturation value of $0.57 \mathrm{kGOe}$ to $3.70 \mathrm{kGOe}$. The increase in the saturation value of the magnetic material resulted in an increase in the degree of magnetization, thereby increasing the reflection loss value of the PMC more than twice from $7.95 \mathrm{~dB}$ to $18.84 \mathrm{~dB}$ after the addition of $\mathrm{Cu}$ doping.

\section{ACKNOWLEDGEMENT}

Researchers would like to thank PSTNT BATAN for allowing researchers to use the facilities provided, as well as Metallurgical Engineering UNJANI and all parties who have helped the author in completing this research. Main contibutor Author Latifah, Sri mulyati and Fadhil, Muhammad.

\section{REFERENCES}

[1]. P. Ambardi, Y.M. Sait, and D.A. Pradoto. "Efek penambahan partikel barium heksaferrit $\left(\mathrm{BaFe}_{12} \mathrm{O}_{19}\right)$, neodybium $(\mathrm{NdFeB})$ dan grafit $(\mathrm{C})$ terhadap kemampuan penyerapan gelombang radar pada cat berbasis polyurethane Fr 2/55 top coat". in Proc. SNIJA, 2015, pp. 403-409.

[2]. W. William, T.R. Simbolon, H. Ginting, P. Sardjono, and M. Muljadi. "Pengaruh waktu dry milling terhadap karakteristik dan sifat magnet permanen Nd-Fe-B”. Journal of SPEKTRA, vol. 1, pp.17-22, Aug. 2016.

[3]. Y.J. Wong, H.W.Chang, Y.I. Lee, W.C. Chang, C.H. Chiu, and C.C. Mo. "Coercivity enhancement of thicker sintered ndfeb magnets by grain boundary diffusion with low-melting Tb75" $\mathrm{xCexCu25(x=0-}$ 45) alloys". Journal of Magnetism and Magnetic Materials, vol. 515, pp. 1-6, Dec. 2020.

[4]. L. Jiajie et al. "Tuning magnetic properties, thermal stability and microstructure of ndfeb magnets with diffusing Pr-Zn films". Journal of Materials 
Science \& Technology, vol. 41, pp. 81-87, Mar. 2020.

[5]. J. Chen, et al. "Rare earth passivation and corrosion resistance of zinc coated $\mathrm{NdFeB}$ magnets". Journal of Rare Earths, In Press, Nov. 2020.

[6]. G. Huang, L. Lou, W. Songa, M. Li, F. Hou, and X. Li. "Microstructure and magnetic properties of $(\mathrm{SmCo}+\mathrm{FeCo}) / \mathrm{NdFeB}$ multicomponent nanocomposite magnets fabricated by hptc with change in heating temperature and composition". Journal of Rare Earths, vol. 38, pp.742-748, Jul. 2020.

[7]. Y. Zhou et al. "Magnetic properties of smart textile fabrics through a coating method with NdFeB Flake-like microparticles". Journal of Engineered Fibers and Fabrics, vol. 14, pp. 1-7, Jul. 2019.

[8]. C. Huber, et al. "Coercivity enhancement of selective laser sintered $\mathrm{NdFeB}$ magnets by grain boundary infiltration". Acta Materialia, vol.172. pp.66-71, Jun. 2019.

[9]. G. Sadullahoglu, B. Altuncevahir, and A.O. Addemir. "Effect of $\mathrm{Al}$ and $\mathrm{Cu}$ additions on microstructure and magnetic properties of $\mathrm{NdTb}-\mathrm{FeCo}-\mathrm{B}$ magnets". Acta Physica Polonica A, vol. 125, No. 5, pp. 1172-1175, 2014.

[10] Callister, William Jr. "Material Science and Engineering, An Introduction". 9th ed., John Wiley \& Sons Inc., 2013.

[11]. H.X. Zeng, Z.W. Liu, J.S. Zhang, X.F. Liao, and H.Y. Yu. "Towards the diffusion source cost reduction for ndfeb grain boundary diffusion process". Journal of Materials Science \& Technology, vol. 36, pp. 50-54, Jan. 2020.

[12]. Y. Liu et al. "Magnetic properties and microstructure evolution of in situ tb-cu diffusion treated hot-deformed Nd-Fe-B magnets". Journal of Magnetism and Magnetic Materials, vol. 504, pp. 1-8, Feb. 2020.

[13]. J. Gibran, S.M. Latifah, and D.H. Prajitno. "Synthesis polymer matrix composite epoxy FeNdB-Mn for radar absorbing material application". International Journal of Mechanical Engineering Technologies and Applications, vol. 2, pp. 1-8, 2021. 